Brit. Heart F., 1969, 31, 133.

CASE REPORTS

\title{
Fistula Between Aorta and Left Atrium Due to Bacterial Endocarditis
}

\author{
ALAN EBRINGER, GIDEON GOLDSTEIN, AND GRAEME SLOMAN \\ From the Clinical Research Unit, Walter and Eliza Hall Institute, and the Cardiac Department, \\ Royal Melbourne Hospital, Melbourne, Victoria, Australia
}

Bacterial endocarditis of the aortic valve may lead to aortic regurgitation, or the aortic wall may become affected with perforation into the right atrium, right ventricle, or left ventricle. Perforation from the aorta into the left atrium forming an aorto-left atrial fistula is rare, and diagnosis is difficult because it closely mimics the features of mitral incompetence (Kay et al., 1959). This problem is illustrated by the present case.

\section{Case Report}

In 1955, an 11-year-old girl presented with haematemesis, melaena, and hepatosplenomegaly. Cardiac examination was normal. A splenic venogram indicated a pressure of $350 \mathrm{~mm} . \mathrm{H}_{2} \mathrm{O}$, normal splenic and portal veins, and oesophageal varices. Biopsy showed the finely nodular liver of "chronic, non-suppurative viral hepatitis". A porta-caval anastomosis was performed. Review in hospital in 1964 confirmed advanced inactive cirrhosis. Cardiac examination was normal.

Occurrence of Bacterial Endocarditis. In September 1965 the patient presented with shortness of breath, jaundice, and ankle swelling. The temperature was $37 \cdot 2^{\circ} \mathrm{C}$, the pulse 76 a minute, and the blood pressure $110 / 60 \mathrm{~mm}$. Hg. A soft apical systolic murmur was noted for the first time. There was a normocytic normochromic anaemia ( $\mathrm{Hb} 10.6 \mathrm{~g} . / 100 \mathrm{ml}$.), a normal white cell count of $7000 / \mathrm{cu} . \mathrm{mm}$., and a reticulocytosis of 3 per cent. The serum bilirubin was $4.5 \mathrm{mg}$. $/ 100 \mathrm{ml}$., alkaline phosphatase 65 King-Armstrong units, aspartate transaminase (SGOT) 76 units, and ESR (Westergren) $57 \mathrm{~mm} . / \mathrm{hr}$. The Wassermann and gonococcal complement-fixation tests were negative. Microscopy of the urine was unremarkable. Soon after admission she became febrile $\left(38.6^{\circ} \mathrm{C}\right.$.), and a dental abscess was diagnosed. Penicillin $\mathrm{G}$ was given and a molar tooth was extracted; Streptococcus viridans and group A betahaemolytic streptococci were cultured from the pus. The systolic murmur became louder and was maximal at the apex, and there was an early diastolic murmur. The diagnoses were bacterial endocarditis, aortic incompetence, and mitral incompetence. The causative organism was presumed to be a streptococcus, but four blood cultures were sterile. Penicillin G, two million units daily, and cephalosporin, $1 \mathrm{~g}$. daily, were given, and the fever subsided within 5 days. Treatment was continued with $\mathbf{4 0}$ million units penicillin $\mathrm{G}$ and $2 \mathrm{~g}$. chloramphenicol daily intravenously, and probenecid orally, for 8 weeks. Though the infecting organism appeared to be eliminated, the breathlessness increased and cardiac failure developed. A chest $x$-ray showed cardiac enlargement, with pulmonary venous congestion. The findings from special investigations led to the erroneous diagnosis of combined aortic and mitral incompetence. Surgical replacement of the aortic and mitral valves was considered but not acted on, because her advanced liver disease made it seem unlikely that she could tolerate double valve replacement. Death occurred suddenly two weeks after she left hospital.

Haemodynamic and Radiological Studies. The pulmonary artery systolic pressure was raised to $80 \mathrm{~mm}$. Hg, the indirect left atrial pressure was raised to a mean of $35 \mathrm{~mm} . \mathrm{Hg}$, and the right atrial pressure was raised to a mean of $30 \mathrm{~mm} . \mathrm{Hg}$ (Table). Cine-aortography showed aortic regurgitation and appearances that were interpreted as considerable mitral regurgitation. Left ventriculography showed a large chamber with moderate to severe mitral incompetence. The anatomy of the mitral valve was not clearly shown.

Necropsy Findings. Necropsy revealed a cirrhotic liver weighing $1475 \mathrm{~g}$., and the porta-caval anastomo133 
TABLE

PRESSURE MEASUREMENTS AT CARDIAC CATHETERIZATION

\begin{tabular}{l|c|c}
\hline \multirow{1}{*}{ Site } & \multicolumn{2}{|c}{ Pressure (mm. Hg) } \\
\cline { 2 - 3 } & Systolic/diastolic & Mean \\
\hline Pulmonary artery & $80 / 40$ & 55 \\
Pulmonary capillary & $\mathrm{v}=35$ & 30 \\
Right atrium & $\mathrm{a}=35$ & 30 \\
Aorta & $\mathrm{v}=40$ & 85 \\
Left ventricle & $130 / 60$ & \\
\hline
\end{tabular}

ventricular wall being greatly thickened. The aortic valve showed no vegetations, but there was a transverse tear in the middle of the left coronary cusp, this being the cause of the aortic regurgitation. There was a $0.5 \mathrm{~cm}$. transverse tear in the left coronary sinus of Valsalva allowing direct communication between the aorta and the left atrium (Fig. 1 and 2). The mitral valve leaflets were competent.

Retrospective Review of Cine-angiography. The films showed evidence of an aneurysm, probably a false aneurysm, arising from the region of the rupture in the left aortic sinus. In both projections the aneurysm was overlying the left atrium. During thoracic aortography

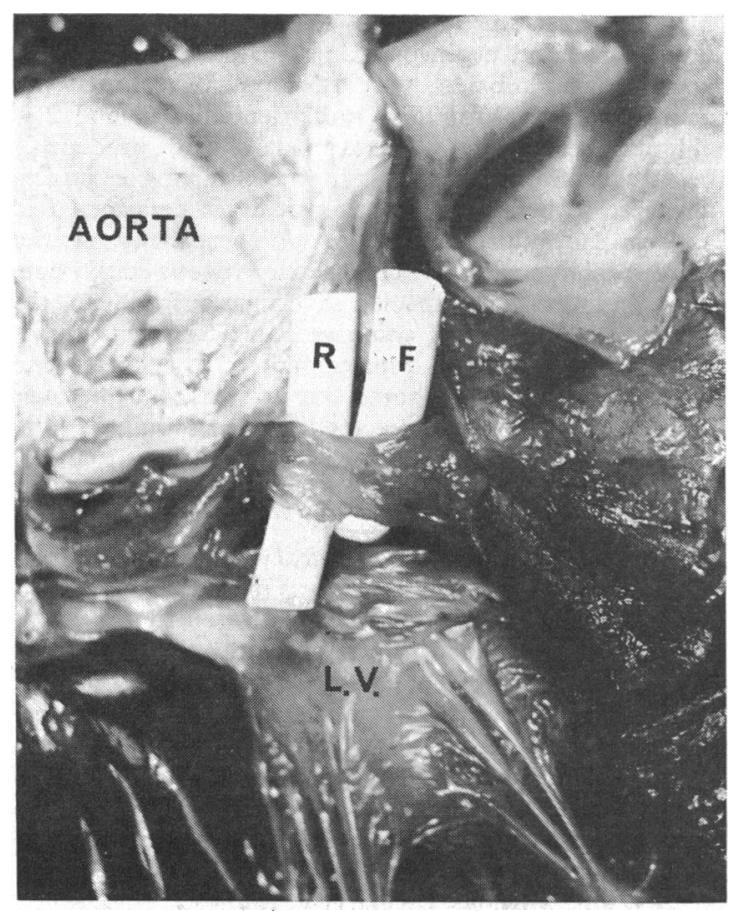

Fig. 1.-The heart is opened to show a ruptured cusp (R) which communicates with the left ventricle (L.V.) and a fistula (F) which communicates with the left atrium.

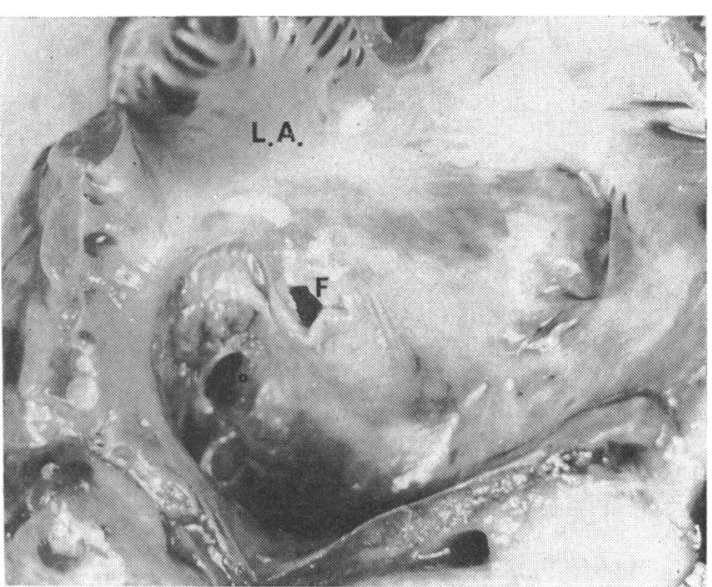

FIG. 2.-Fistulous communication (F) between aorta and left atrium (L.A.), as seen from the atrial side.

regurgitation first occurred through the aortic valve, then the aneurysm filled, and finally the left atrium was outlined. Review of the left ventriculogram showed that regurgitation occurred through the mitral valve, with opacification of the left atrium. Later the aorta and aneurysm filled. It is uncertain whether, at the time of the angiograms, there was a small fistula between the aorta and the left atrium or whether the aneurysm was intact, rupturing later into the atrium, perhaps as the cause of death.

\section{Discussion}

Rupture from the aorta into the left atrium is rare. The usual cause is dissecting aneurysm, but only 9 of 1197 cases of dissecting aneurysm reviewed by Boyd (1924) had ruptured into the left atrium. Rupture of congenital aneurysmal dilatation of the sinuses of Valsalva is usually into the right atrium or right ventricle ( $\mathrm{Lin}$, Crockett, and Dimond, 1956); there is only one recorded case of rupture into the left atrium (Kay et al., 1959).

Cirrhosis of the liver and the porta-caval shunt probably predisposed our patient to bacterial endocarditis, since cirrhosis is associated with impairment of host defence mechanisms and blood-stream invasion with organisms of normally low pathogenicity (Uwaydah and Weinberg, 1965; Goldstein, Cowling, and Wall, 1965). Patients with negative blood cultures tend to respond poorly to chemotherapy, because atypical organisms resistant to antibiotics may be present (Lerner and Weinstein, 1966.)

Cine-aortography is helpful in assessing aortic incompetence (Taubman, Goodman, and Steiner, 1966), and left ventriculography is the best method for assessing whether damage to the aortic or mitral 
valve is the predominant lesion (Rees, Jefferson and Harris, 1965). In our case the cine studies were interpreted as showing combined aortic and mitral incompetence, but an aneurysm and possibly a fistula from the sinus of Valsalva into the left atrium was not recognized. Indicator dilution techniques have been developed for measuring combined aortic and mitral insufficiency (Bloomfield, Battersby, and Sinclair-Smith, 1966), and an anomalous result in our patient might have drawn attention to the alternative diagnosis of aorto-left atrial fistula.

In our patient surgical replacement of both the aortic and mitral valves was deferred because of her severe liver disease, and the knowledge that in 10 such procedures the mean perfusion time was 2 hours 26 minutes, with an anoxic period of 68 minutes (Iben, Hurley, and Shumway, 1965); a correct diagnosis might have led to an attempt at surgical repair in the hope that a relatively short perfusion time would suffice.

Over 90 patients with rupture of a sinus of Valsalva have been successfully treated with an operative mortality of 20 per cent (Parker and Connell, 1965); successful repair is more frequent with a rupture of a congenital aneurysm than with a rupture due to bacterial endocarditis (Paton et al., 1965). All but one of the successful repairs of a ruptured sinus of Valsalva concerned ruptures into the right atrium. The single successful repair of a sinus of Valsalva-left atrial fistula was that described by Kay et al. (1959), but further surgical successes could follow early recognition of this complication.

\section{Summary}

The present report is, to our knowledge, the first recorded case of an aorto-left atrial fistula due to bacterial endocarditis. A young woman with cirrhosis of the liver had bacterial endocarditis and developed aortic incompetence and features suggesting mitral incompetence. Cineradiology showed aortic incompetence and mitral incompetence; an aneurysm bulging from the aorta into the left atrium was recognized on review after a necropsy diagnosis of aorto-left atrial fistula. Necropsy revealed a tear in the left coronary leaflet causing aortic regurgitation, and a fistula from the left sinus of Valsalva to the left atrium. The mitral leaflets were normal.

We would like to thank Dr. Ian Mackay for permission to publish this case and Miss Winifred Kirton for help in preparing the manuscript.

We are deeply grateful to Professor W. S. C. Hare for comments in the interpretation of the radiological studies.

A.E. was in receipt of a Fellowship from Drug Houses of Australia Limited, and G.G. was supported by a grant from the National Health and Medical Research Council of Australia.

\section{References}

Bloomfield, D. A., Battersby, E. J., and Sinclair-Smith, B. C. (1966). Use of indicator dilution techniques in measuring combined aortic and mitral insufficiency. Circulat. Res., 18, 97.

Boyd, L. J. (1924). A study of four thousand reported cases of aneurysm of the thoracic aorta. Amer. F. med. Sci., $168,654$.

Goldstein, G., Cowling, D. C., and Wall, A. J. (1965). Infection with Mima polymorpha: fatal meningitis and septicaemia. Aust. Ann. Med., 14, 167.

Iben, A. B., Hurley, E. J., and Shumway, N. E. (1965). Surgery for combined lesions of the aortic and mitral valves, Amer. F. Surg., 110, 262.

Kay, J. H., Anderson, R. M., Lewis, R. R., and Reinberg, M. (1959). Successful repair of sinus of Valsalva-left atrial fistula. Circulation, 20, 427.

Lerner, P. I., and Weinstein, L. (1966). Infective endocarditis in the antibiotic era. New Engl. F. Med., 274, 323.

Lin, T. K., Crockett, J. E., and Dimond, E. G. (1956). Ruptured congenital aneurysm of the sinus of Valsalva. Amer. Heart f., 51, 445.

Parker, J. O., and Connell, W. F. (1965). Ruptured congenital aneurysm of the sinus of Valsalva. Canad. med. Ass. F., 92, 1314.

Paton, B. C., MacMahon, R. A., Swan, H., and Blount, S. G. (1965). Ruptured sinus of Valsalva. Arch. Surg., 90, 209.

Rees, R. S. O., Jefferson, K. E., and Harris, A. M. (1965). Cine-angiocardiography of the mitral valve. Brit. Heart f., 27, 498.

Taubman, J. O., Goodman, D. J., and Steiner, R. E. (1966). The value of contrast studies in the investigation of aortic valve disease. Clin. Radiol., 17, 23.

Uwaydah, M. M., and Weinberg, A. N. (1965). Bacterial endocarditis-a changing pattern. New Engl. f. Med., 273, 1231. 